\title{
Evidence for Abnormal Regulation of Circulating 1 $\alpha, 25-$ Dihydroxyvitamin D in Patients with Sarcoidosis and Normal Calcium Metabolism
}

\author{
Paula H. Stern, Jose De Olazabal, and Norman H. Bell, Department of \\ Pharmacology, Northwestern University Medical School, \\ Chicago, Illinois 60611; Veterans Administration Hospital and \\ Departments of Medicine and Pharmacology, Medical University of \\ South Carolina, Charleston, South Carolina 29403
}

\begin{abstract}
A B S TRACT The effects of vitamin D, $2.5 \mathrm{mg}$ $(100,000 \mathrm{U}) / \mathrm{d}$ for $4 \mathrm{~d}$, on serum calcium, serum 25 hydroxyvitamin D (25-OHD), and serum $1 \alpha, 25$-dihydroxyvitamin $\mathrm{D}\left[1 \alpha, 25(\mathrm{OH})_{2} \mathrm{D}\right]$ were compared in 17 normal subjects and 6 patients with sarcoidosis who had normocalcemia and no history of hypercalcemia. The diagnosis was confirmed histologically in each of them. Vitamin D increased mean serum 25-OHD from $30 \pm 4$ to $99 \pm 15 \mathrm{ng} / \mathrm{ml}(P<0.001)$ and did not change mean serum $1 \alpha, 25(\mathrm{OH})_{2} \mathrm{D}(32 \pm 3$ vs. $29 \pm 3 \mathrm{pg} / \mathrm{ml})$ or mean serum calcium $(9.5 \pm 0.1 \mathrm{vs} .9 .6 \pm 0.1 \mathrm{mg} / \mathrm{dl})$ in the normal subjects. In contrast, vitamin $D$ increased mean serum 25-OHD from $19 \pm 3$ to $65 \pm 19 \mathrm{ng} / \mathrm{ml}(p<0.05)$, increased mean serum $1 \alpha, 25(\mathrm{OH})_{2} \mathrm{D}$ threefold from $40 \pm 7$ to $120 \pm 24 \mathrm{pg} / \mathrm{ml}$, and increased mean serum calcium from $9.4 \pm 0.2$ to $9.8 \pm 0.2 \mathrm{mg} / \mathrm{dl}(P<0.01)$. There was a significant positive correlation between the serum $1 \alpha, 25(\mathrm{OH})_{2} \mathrm{D}$ and serum calcium in these individuals $(r=0.663, P<0.01)$ but not in the normal subjects. The results $(a)$ provide further evidence for abnormal regulation of circulating $1 \alpha, 25(\mathrm{OH})_{2} \mathrm{D}$ in sarcoidosis and $(b)$ indicate that the abnormality may exist in patients with normal calcium metabolism. Thus, the defect in vitamin $\mathrm{D}$ metabolism in sarcoid apparently is more common than was previously recognized.
\end{abstract}

\section{INTRODUCTION}

Available evidence indicates that the abnormal calcium metabolism in sarcoidosis results from increases

Dr. Stern is the recipient of a Career Development Award from the U. S. Public Health Service. Dr. Bell was Veterans Administration Medical Investigator. Address reprint requests to Dr. Bell in Charleston.

Received for publication 16 June 1980 and in revised form 11 July 1980. in circulating $1 \alpha, 25$-dihydroxyvitamin $\mathrm{D}$ [ $1 \alpha, 25$ $\left.(\mathrm{OH})_{2} \mathrm{D}\right] .^{1}$ Mean plasma $1 \alpha, 25(\mathrm{OH})_{2} \mathrm{D}$ is increased and serum immunoreactive parathyroid hormone is suppressed in patients with sarcoidosis and hypercalcemia who do not have primary hyperparathyroidism $(1,2)$. Further vitamin $\mathrm{D}, 0.25 \mathrm{mg}(10,000 \mathrm{U}) / \mathrm{d}$ for $12 \mathrm{~d}$, increases serum $1 \alpha, 25(\mathrm{OH})_{2} \mathrm{D}$ abnormally in patients with normocalcemia and a history of hypercalcemia but does not alter serum $1 \alpha, 25(\mathrm{OH})_{2} \mathrm{D}$ abnormally in subjects or patients with sarcoid who have normal calcium metabolism (1). Thus, the increased sensitivity to vitamin $\mathrm{D}$ in sarcoid results from increases in serum $1 \alpha, 25(\mathrm{OH})_{2} \mathrm{D}$. Finally, hypercalcemia and the increases in circulating $1 \alpha, 25(\mathrm{OH})_{2} \mathrm{D}$ are corrected after treatment with glucocorticoids $(1,2)$.

In our previous investigation this dose of vitamin D produced a modest but significant increase in mean serum $1 \alpha, 25(\mathrm{OH})_{2} \mathrm{D}$ (which remained well within the normal range) in the patients with sarcoidosis and normal calcium metabolism (1). To determine whether an abnormal response of serum $1 \alpha, 25(\mathrm{OH})_{2} \mathrm{D}$ might be elicited with a larger dose of vitamin $\mathrm{D}$, the effects of $2.5 \mathrm{mg}(100,000 \mathrm{U}) / \mathrm{d}$ for $4 \mathrm{~d}$ of the vitamin were compared in normal subjects and patients with sarcoidosis who had a normal serum calcium and had never had hypercalcemia.

\section{METHODS}

17 adult normal subjects, 9 men and 8 women ranging in age from 21 to $56 \mathrm{yr}$, and 6 patients with sarcoidosis, 4 men and 2 women ranging in age from 23 to $58 \mathrm{yr}$, were studied. They were hospitalized at the Clinical Research Center of the Indiana University Medical School or of the Medical University of South Carolina. Each of them was given a con-

\footnotetext{
${ }^{1}$ Abbreviations used in this paper: $1 \alpha, 25(\mathrm{OH})_{2} \mathrm{D}, 1 \alpha, 25-$ dihydroxyvitamin $\mathrm{D}$; 25-OHD, 25-hydroxyvitamin D.
} 
TABLE I

Clinical Findings in Patients with Sarcoidosis

\begin{tabular}{ccccccc}
\hline Patient & Age & Sex & Serum Ca & Urinary Ca & Biopsy & $\begin{array}{c}\text { Hyper- } \\
\text { (alcemia* }\end{array}$ \\
\hline & $y r$ & & $m g / d l$ & $m g / d$ & & \\
A & 58 & F & 9.0 & 112 & + & - \\
B & 27 & M & 9.4 & - & + & - \\
C & 33 & F & 9.2 & 174 & + & - \\
D & 26 & M & 9.5 & 255 & + & - \\
E & 31 & M & 9.6 & 86 & + & - \\
F & 23 & M & 9.6 & 156 & + & - \\
\hline
\end{tabular}

* By history.

stant daily diet estimated to contain $400 \mathrm{mg} / \mathrm{d}$ of calcium and $900 \mathrm{mg}$ of phosphorus and a constant fluid intake. Vitamin $\mathrm{D}_{2}, 2.5 \mathrm{mg}(100,000 \mathrm{U}) / \mathrm{d}$ for $4 \mathrm{~d}$, was given as a single morning dose. Fasting blood samples were obtained on the 1 st $d$ before vitamin $D$ and again on the 5 th $d, 24 \mathrm{~h}$ after the last dose of the vitamin, for determination of calcium $(3,4)$, phosphorus (5), creatinine $(6,7), 25$-hydroxyvitamin D (25$\mathrm{OHD}$ ), and $1 \alpha, 25(\mathrm{OH})_{2} \mathrm{D}$. In the patients, 24 -h urines were collected and analyzed for calcium (4).

Serum 25-OHD was measured in triplicate by the competitive protein-binding method with vitamin D-deficient rat serum (8) as described (1). The normal range for the method in this laboratory is from 10 to $80 \mathrm{ng} / \mathrm{ml}(1)$.

Serum $1 \alpha, 25(\mathrm{OH})_{2} \mathrm{D}$ was measured by bioassay as described $(1,9)$. The mean value in normal subjects is $32 \pm 2 \mathrm{pg} / \mathrm{ml}$ and the range is from 15 to $55 \mathrm{pg} / \mathrm{ml}(n=33)$. The $95 \%$ confidence values (mean $\pm 2 \mathrm{SD}$ ) are $13-52 \mathrm{pg} / \mathrm{ml}$. The interassay variation is $9.1 \%(n=17)$.

Student's $t$ test was used to determine the significance of differences between paired or unpaired samples (10). Cor- relation coefficient was carried out with a Hewlett-Packard calculator (model 9815A, Hewlett-Packard Co., Palo Alto, Calif.).

\section{RESULTS}

The diagnosis of sarcoidosis was confirmed histologically in each of the patients (Table I). None of them had had hypercalcemia and none had received steroids for at least $1 \mathrm{yr}$ before the study. Serum calcium was normal in each of them and urinary calcium was above $200 \mathrm{mg} / \mathrm{d}$ in one of them.

The effects of vitamin D, $2.5 \mathrm{mg} / \mathrm{d}$ for $4 \mathrm{~d}$, were examined in 17 normal subjects and in 6 patients with sarcoid (Table II). In the normal subjects vitamin D increased mean serum 25-OHD significantly, but did not alter mean serum calcium, phosphorus, creatinine, or $1 \alpha, 25(\mathrm{OH})_{2} \mathrm{D}$.

In contrast, vitamin $\mathrm{D}$ increased mean serum calcium, phosphorus, 25-OHD, and $1 \alpha, 25(\mathrm{OH})_{2} \mathrm{D}$ and did not change mean serum creatinine in the patients. The increases in serum $1 \alpha, 25(\mathrm{OH})_{2} \mathrm{D}$ ranged from $57 \%$ in patient $\mathrm{F}$ to $797 \%$ in patient $\mathrm{D}$ and averaged $195 \%$. Whereas before vitamin $\mathrm{D}$ mean serum $1 \alpha, 25(\mathrm{OH})_{2} \mathrm{D}$ was not significantly different between the normal subjects and patients, after vitamin $\mathrm{D}$ it was significantly higher in the patients than in the normal subjects $(P<0.001)$. Furthermore, there was a significant positive correlation between the serum $1 \alpha, 25(\mathrm{OH})_{2} \mathrm{D}$ and serum calcium in the patients (Fig. 1) but not in the normal subjects. Urinary calcium averaged 116, 139, 239, 72, and $214 \mathrm{mg} / \mathrm{d}$

TABLE II

Effects of Vitamin $D_{2}$ on Serum Calcium, Phosphorus, Creatinine, 25-OHD, and $1 \alpha, 25(\mathrm{OH})_{2} \mathrm{D}$

\begin{tabular}{lccccc}
\hline & Calcium & Phosphorus & $\begin{array}{c}\text { Serum } \\
\text { creatinine }\end{array}$ & $25-\mathrm{OHD}^{*}$ & $1 \alpha, 25(\mathrm{OH})_{2} \mathrm{D}$ \\
\hline & $m g / d l$ & $m g / d l$ & $m g / d l$ & $n g / m l$ & $m g / m l$ \\
Normal subjects (17) & & & & & \\
$\quad$ Control & $9.5 \pm 0.1$ & $4.1 \pm 0.1$ & $0.9 \pm 0.1$ & $30 \pm 4$ & $32 \pm 3$ \\
$\quad$ Vitamin D $\ddagger$ & $9.6 \pm 0.1$ & $4.1 \pm 0.1$ & $1.0 \pm 0.1$ & $99 \pm 15$ & $29 \pm 3$ \\
$P$ value & $\mathrm{NS}$ & $\mathrm{NS}$ & $\mathrm{NS}$ & $<0.001$ & $\mathrm{NS}$ \\
$\begin{array}{l}\text { Patients (6) } \\
\text { Control }\end{array}$ & $9.4 \pm 0.2$ & $3.9 \pm 0.3$ & $1.0 \pm 0.1$ & $19 \pm 3$ & $40 \pm 7$ \\
Vitamin D & $9.8 \pm 0.2$ & $4.2 \pm 0.3$ & $1.0 \pm 0.1$ & $65 \pm 19$ & $120 \pm 24 \S$ \\
$P$ value & $<0.01$ & $<0.01$ & $\mathrm{NS}$ & $<0.05$ & $\mathrm{NS}$ \\
\hline
\end{tabular}

Results are given as mean $\pm \mathrm{SE}$.

* Serum 25-OHD was measured in 12 normals before vitamin $\mathrm{D}$ and in 9 normals after vitamin $\mathrm{D}$.

$\$$ Vitamin $D_{2}, 2.5 \mathrm{mg} / \mathrm{d}$ for $4 \mathrm{~d}$, was given by mouth.

$\S$ The difference between control and treated values is not significant $(t=2.05)$ because of the marked increase in serum $1 \alpha, 25(\mathrm{OH})_{2} \mathrm{D}$ from 34 to $305 \mathrm{pg} / \mathrm{ml}$ in patient D. If these values are omitted, mean serum $1 \alpha, 25(\mathrm{OH})_{2} \mathrm{D}$ increased from $42 \pm 8$ to $8.3 \pm 13 \mathrm{pg} / \mathrm{ml}(\mathrm{t}=6.06, P<0.01)$ in the other patients. 


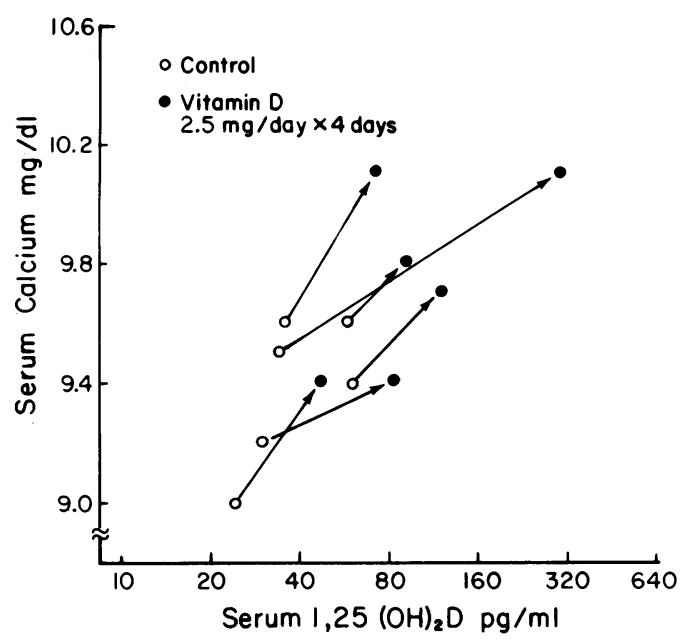

FIGURE 1 Effects of vitamin $\mathrm{D}_{2}$ on serum $1 \alpha, 25(\mathrm{OH})_{2} \mathrm{D}$ and serum calcium in six patients with sarcoidosis. Note that the serum $1 \alpha, 25(\mathrm{OH})_{2} \mathrm{D}$ is drawn on a semi-log plot. $r=0.663 ; P<0.01$.

in five patients (A, C, D, E, and $F$, respectively) during the $4-d$ period of vitamin $D$ administration and therefore changed very little (Table I).

\section{DISCUSSION}

Our studies show a clear impairment in the regulation of circulating $1 \alpha, 25(\mathrm{OH})_{2} \mathrm{D}$ in a group of patients with sarcoid and apparent normal calcium metabolism. The results provide additional evidence that increases in serum $1 \alpha, 25(\mathrm{OH})_{2} \mathrm{D}$ are responsible for the abnormal calcium metabolism in this disease $(1,2)$ and suggest that the defect in vitamin $\mathrm{D}$ metabolism is more common than was previously recognized.

The mechanism for the abnormal vitamin D metabolism in sarcoidosis has not been elucidated. Hypercalcemia was recently reported in a patient with sarcoid who had developed renal failure and had undergone bilateral nephrectomy in preparation for kidney transplantation (11). The hypercalcemia responded to steroids and was associated with suppression of serum immunoreactive parathyroid hormone and increases in serum $1 \alpha, 25(\mathrm{OH})_{2} \mathrm{D}$. Serum calcium and serum $1 \alpha, 25(\mathrm{OH})_{2} \mathrm{D}$ values correlated with each other. The findings in this patient support the possibility that in sarcoid the production of $1 \alpha, 25(\mathrm{OH})_{2} \mathrm{D}$ may occur in tissues other than that of the kidney.

Our observations in normal subjects suggest that the renal production of $1 \alpha, 25(\mathrm{OH})_{2} \mathrm{D}$ is tightly regulated. The findings are consistent with those obtained in patients with vitamin $\mathrm{D}$ intoxication, who show increases in serum 25-OHD and not $1 \alpha, 25(\mathrm{OH})_{2} \mathrm{D}$ (12). In the rat, vitamin $D$ intoxication with hypercalcemia is characterized by increases in serum 25$\mathrm{OHD}$ and decreases in serum $1 \alpha, 25(\mathrm{OH})_{2} \mathrm{D}$ (13). In contrast, vitamin $\mathrm{D}$ intoxication in the cow is characterized by increases in all of the metabolites of vitamin D including the vitamin itself, 25-OHD, 24,25dihydroxyvitamin $\mathrm{D}$, as well as $1 \alpha, 25(\mathrm{OH})_{2} \mathrm{D}(14)$.

Urinary calcium did not change appreciably during the $4 \mathrm{~d}$ of treatment with vitamin $\mathrm{D}$ in our patients despite the increases in serum $1 \alpha, 25(\mathrm{OH})_{2} \mathrm{D}$ and modest but significant increases in serum calcium, which remained within the normal range. We demonstrated previously in two patients with sarcoid and a history of hypercalcemia that vitamin $\mathrm{D}, 250 \mu \mathrm{g} / \mathrm{d}$ for $12 \mathrm{~d}$, increased both serum $1 \alpha, 25(\mathrm{OH})_{2} \mathrm{D}$ and urinary calcium. Serum calcium remained within the normal range. The increases in serum $1 \alpha, 25(\mathrm{OH})_{2} \mathrm{D}$ were noted by the 5 th $\mathrm{d}$ of administration of vitamin $\mathrm{D}$ and preceded the increases in urinary calcium. Urinary calcium did not change during the initial $4 \mathrm{~d}$ of vitamin D. Thus, the period of observation in the present study was too short an interval for an increase in urinary calcium to occur.

\section{ACKNOWLEDGMENTS}

We thank Sheryl Shaw and Anne Greene for excellent technical assistance and the nursing, dietary, and laboratory staffs of the Clinical Research Centers in Indianapolis and Charleston.

Supported in part by research funds from the Veterans Administration and by grants AM 11262, MO1 RR 750 (Clinical Research Center), and MO1 RR 1070 (Clinical Research Center) from the U. S. Public Health Service.

\section{REFERENCES}

1. Bell, N. H., P. H. Stern, E. Pantzer, T. K. Sinha, and H. F. DeLuca. 1979. Evidence that increased circulating $1 \alpha, 25$-dihydroxyvitamin $\mathrm{D}$ is the probable cause for abnormal calcium metabolism in sarcoidosis. J. Clin. Invest. 64: 218-225.

2. Papapoulos, S. E., T. L. Clemens, L. J. Fraher, I. G. Lewin, L. M. Sandler, and J. L. H. O'Riordan. 1979. 1,25-dihydroxycholecalciferol in the pathogenesis of the hypercalcemia of sarcoidosis. Lancet I: 627-630.

3. Connerty, H. V., and A. R. Briggs. 1966. Determination of serum calcium by means of orthocresolphthalein. Am. J. Clin. Pathol. 45: 290-296.

4. Baginsky, E. S., S. S. Marie, W. L. Clark, and B. Zak. 1973. Direct microdetermination of calcium. Clin. Chem. Acta. 46: 49-54.

5. Fiske, C. H., and Y. Subbarow. 1925. The colorimetric determination of phosphorus. J. Biol. Chem. 66: 375-400.

6. Bartels, H., and M. Bohmer. 1971. Eine Mikromethode zur Kreatinin Bestimmung. Clin. Chem. Acta. 32: 81-85.

7. Folin, O., and H. Wu. 1919. A system of blood analysis. J. Biol. Chem. 38: 81-110.

8. Belsey, R. E., H. F. DeLuca, and J. T. Potts, Jr. 1974. A rapid assay for 25-OH-vitamin $\mathrm{D}_{3}$ without preparative chromatography. J. Clin. Endocrinol. Metab. 38: 10461051.

9. Stern, P. H., A. J. Hamstra, H. F. DeLuca, and N. H. Bell. 1978. A bio-assay capable of measuring 1 picogram of 1,25-dihydroxyvitamin $\mathrm{D}_{3}$. J. Clin. Endocrinol. Metab. 46: 891-901.

10. Steele, R. G., and J. H. Torrie, 1980. Principles and 
Procedures of Statistics. McGraw-Hill Book Co., New York. 2nd edition. 86-282.

11. Barbour, G. L., J. W. Coburn, A. W. Norman, and E. Slatopolsky. 1980. Non-renal hypercalcemia in sarcoidosis. Clin. Res. 28: 46A, (Abstr.)

12. Hughes, M. R., D. J. Baylink, P. G. Jones, and M. R. Haussler. 1976. Radioligand receptor assay for 25hydroxyvitamin $\mathrm{D}_{2} / \mathrm{D}_{3}$ and $1 \alpha, 25$-dihydroxyvitamin $\mathrm{D}_{2} /$ $\mathrm{D}_{3}$. J. Clin. Invest. 58: 61-70.

13. Hughes, M. R., D. J. Baylink, W. A. Gonnerman, S. U. Toverud, W. K. Ramp, and M. R. Haussler. 1977. In- fluence of dietary vitamin $\mathrm{D}_{3}$ on the circulating concentration of its active metabolites in the chick and rat. Endocrinology. 100: 799-806.

14. Horst, R. L., and E. T. Littledike. 1979. Elevated plasma $1,25(\mathrm{OH})_{2} \mathrm{D}$ following massive vitamin $\mathrm{D}_{3}$ in dairy cattle. In Vitamin D: Basic Research and Its Clinical Application. A. W. Norman, K. Schaefer, D. V. Herrath, H-G. Grigoleit, J. W. Coburn, H. F. DeLuca, E. B. Mawer, and T. Suda, editors. Walter de Gruyter, New York. 999-1001. 